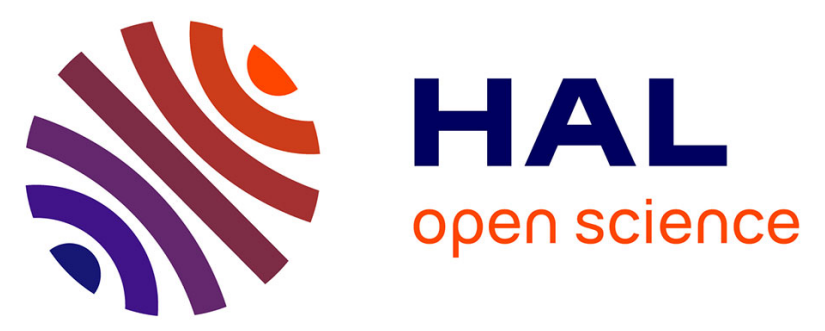

\title{
Activation of the cAMP pathway synergistically increases IL-1-induced IL-6 gene expression in FRTL-5 thyroid cells: Involvement of AP-1 transcription factors
}

Nicolas Szabo-Fresnais, Jean-Paul Blondeau, Martine Pomérance

\section{- To cite this version:}

Nicolas Szabo-Fresnais, Jean-Paul Blondeau, Martine Pomérance. Activation of the cAMP pathway synergistically increases IL-1-induced IL-6 gene expression in FRTL-5 thyroid cells: Involvement of AP-1 transcription factors. Molecular and Cellular Endocrinology, 2008, 284 (1-2), pp.28. 10.1016/j.mce.2007.12.017 . hal-00531979

\section{HAL Id: hal-00531979 \\ https://hal.science/hal-00531979}

Submitted on 4 Nov 2010

HAL is a multi-disciplinary open access archive for the deposit and dissemination of scientific research documents, whether they are published or not. The documents may come from teaching and research institutions in France or abroad, or from public or private research centers.
L'archive ouverte pluridisciplinaire HAL, est destinée au dépôt et à la diffusion de documents scientifiques de niveau recherche, publiés ou non, émanant des établissements d'enseignement et de recherche français ou étrangers, des laboratoires publics ou privés. 


\section{Accepted Manuscript}

Title: Activation of the cAMP pathway synergistically increases IL-1-induced IL-6 gene expression in FRTL-5 thyroid cells: Involvement of AP-1 transcription factors

Authors: Nicolas Szabo-Fresnais, Jean-Paul Blondeau, Martine Pomérance

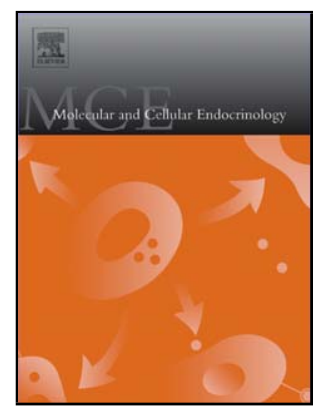

PII: S0303-7207(08)00004-X

DOI: doi:10.1016/j.mce.2007.12.017

Reference: MCE 6782

To appear in: Molecular and Cellular Endocrinology

Received date:

8-11-2007

Revised date: 19-12-2007

Accepted date: 22-12-2007

Please cite this article as: Szabo-Fresnais, N., Blondeau, J.-P., Pomérance, M., Activation of the cAMP pathway synergistically increases IL-1-induced IL-6 gene expression in FRTL-5 thyroid cells: Involvement of AP-1 transcription factors, Molecular and Cellular Endocrinology (2007), doi:10.1016/j.mce.2007.12.017

This is a PDF file of an unedited manuscript that has been accepted for publication. As a service to our customers we are providing this early version of the manuscript. The manuscript will undergo copyediting, typesetting, and review of the resulting proof before it is published in its final form. Please note that during the production process errors may be discovered which could affect the content, and all legal disclaimers that apply to the journal pertain. 


\section{Activation of the CAMP pathway synergistically increases IL-1-induced IL-6 gene expression in FRTL-5 thyroid cells: Involvement of AP-1 transcription factors}

\footnotetext{
Nicolas Szabo-Fresnais ${ }^{a, b}$, Jean-Paul Blondeau ${ }^{a, c}$ and Martine Pomérance ${ }^{a, b}$

a INSERM U 486, Faculté de Pharmacie, F-92296 Châtenay-Malabry, France

b INSERM U 769, Faculté de Pharmacie, F-92296 Châtenay-Malabry, France

C Univ Paris-Sud, CIBLOT-IFR 141, Faculté de Pharmacie, F-92296 Châtenay-

Malabry, France
}

Corresponding author: Dr Martine Pomérance, INSERM U769, 5 rue J.B. Clément, Faculté de Pharmacie, 92296 Châtenay-Malabry, France

Email: martine.pomerance@u-psud.fr 


\section{Abstract}

Interleukin-6 (IL-6) is a multifunctional cytokine involved in autoimmune thyroid diseases such as Hashimoto's thyroiditis and Graves' disease. IL-6 is produced by infiltrating immune cells and by thyrocytes. In the latter cell type, secretion of IL-6 is stimulated notably by interleukin-1 (IL-1), thyroid-stimulating hormone (TSH) or forskolin (Fk), a cAMP elevating agent. We report here that Fk and IL-1 synergistically enhance IL-6 mRNA expression in FRTL-5 thyroid cells by mechanisms involving the CAMP/PKA pathway, and both stabilization of the IL-6 mRNA and activation of the IL-6 promoter. Point mutations or deletions of the main transcription factor binding sites in the IL-6 promoter indicated that the synergistic effect was mainly mediated by the AP-1 site, and that the CRE site contributed to this effect. The DNA binding activity of AP-1 transcription factors and the expression of cFos and Fra-2 proteins, were all enhanced when the cAMP and IL-1 signalling pathways were both stimulated. These findings contribute to elucidating the synergistic mechanisms that regulate IL- 6 secretion by thyroid cells, and suggest that such mechanisms may be involved in the development of thyroid autoimmune disorders.

Keywords: IL-6; IL-1; cAMP; stabilization; AP-1; thyroid cell 


\section{Introduction}

The thyroid gland is one of the organs at the center of autoimmune disorders. In both Hashimoto's thyroiditis and Graves' disease, pro-inflammatory cytokine production is elevated. These cytokines are released by lymphocytes, macrophages, and dendritic cells infiltrating the thyroid gland (Weetman and McGregor, 1994), but also by the thyrocytes themselves. Several cytokines, such as interleukin $1 \beta$ (IL-1), interleukin 6 (IL-6), tumour necrosis factor $\alpha$ (TNF $\alpha$ ), and transforming growth factor $\beta$ are produced in vitro by both nontransformed and transformed thyrocytes (Grubeck-Loebenstein et al., 1989 ; Aust and Scherbaum, 1996), suggesting that these cytokines may act as regulators of thyroid functions. Several studies have shown that some cytokines induce the secretion of other cytokines by thyrocytes. Thus, IL- 6 production is up-regulated by IL- 1 and by TNF $\alpha$ in the FRTL- 5 rat thyroid cell line and in human thyrocytes (Weetman et al., 1990 ; Iwamoto et al., 1991; Diamant et al., 1991).

The function of the thyroid gland is under the hormonal control of thyroidstimulating hormone (TSH), which also up-regulates thyrocyte differentiation and proliferation. CAMP mediates most of the effects of TSH, as a result of the coupling of the $\mathrm{TSH}$ receptor to the Gs protein, and the subsequent activation of adenylyl cyclase. It is well known that patients with Hashimoto's thyroiditis frequently develop hypothyroidism, and have increased serum levels of $\mathrm{TSH}$, and that those with Graves' disease produce thyroid-stimulating antibodies (TSAb) that activate the TSH receptor and mimic the action of the hormone. However, the role of TSH in autoimmune thyroid diseases remains unclear. Activating the TSH receptor may promote the onset of these diseases by facilitating autoimmune activation. Thus, TSH stimulates the expression of thyroid peroxidase and of thyroglobulin, which are both important thyroid autoantigens. TSH, alone or in combination with interferon $\gamma$, induces $\mathrm{MHC}$ class II expression in cultured human thyrocytes from patients with autoimmune thyroid disease (Todd et al., 1987). Moreover, Iwamoto et al. (1991) have reported that TSH synergistically enhances IL-6 production by FRTL-5 cells stimulated by IL-1. This effect has also been obtained using forskolin (Fk), a direct activator of adenylyl cyclase (Kennedy et al., 1992). 
It has been suggested that IL-6, which is a multifunctional cytokine, may be involved in the pathogenesis of autoimmune diseases (Hirano et al., 1990). IL-6 stimulates the proliferation of $\mathrm{T}$ cells and the production of antibodies by $\mathrm{B}$ cells (Kishimoto 2006), and appears to be involved in the recruitment of dendritic cells in the thyroid of rats developing autoimmune thyroid disease (Simons et al., 1998a). The production of large amounts of IL-6 in disease states may also be involved in mediating the release of suppression of self-reactive $T$ cells, resulting in autoimmune disease (Pasare and Medzhitov, 2003). It has also been reported that IL-6 could be a mediator in the inhibition by dentritic cells of thyrocyte growth (Simons et al., 1998b).

Both post-transcriptional and transcriptional regulation appear to be involved in IL-6 gene expression (Vanden Berghe et al., 1998). IL-6 mRNA stability is modulated by stimuli that activate the p38 MAP kinase pathway, and this effect is mediated via AU-rich elements (AREs) localized in the 3'-untranslated region (UTR) of IL-6 mRNA (Miyazawa et al., 1998; Winzen et al., 1999; Neininger et al., 2002). The murine and human 400-bp 5'-flanking region of the IL-6 gene is highly conserved (Tanabe et al., 1988), and contains a number of cis-acting elements, which have been demonstrated to be required for gene induction by a variety of stimuli, and for tissue-specific transcriptional regulation (Vanden Berghe, 2000). Response elements for at least four different classes of transcription factors have been identified in this regulatory region: activator protein-1 (AP-1) (Tanabe et al., 1988), cAMP response elementbinding protein (CREB) (Dendorfer et al., 1994), CCAAT/enhancer binding protein (C/EBP) also known as NF-IL-6 (Akira et al., 1990), and nuclear factor- $\kappa B(N F \kappa B)$ (Libermann and Baltimore, 1990). The NFКB binding site has been reported to be essential for the response of the IL-6 promoter to IL-1 and to TNF $\alpha$ (Libermann and Baltimore, 1990).

In thyroid FRTL-5 cells, the presence of TSH is crucial for the action of TNF $\alpha$ on NF $\kappa B$ activation (Kikumori et al., 2001). However, little, if any, information is available about the molecular mechanisms that lead to the synergistic effects of TSH and cAMP on IL-6 secretion stimulated by IL-1. The present study was carried out using FRTL-5 thyroid cells, which retain most of the features of differentiated follicular thyroid cells, and are suitable for performing reporter gene assays. We found that activating the cAMP pathway has a synergistic effect on IL-1-stimulated IL-6 mRNA expression by inducing both the stabilization of IL-6 mRNA, and the activation of the 
IL-6 promoter. This synergistic effect mainly involves the AP-1 binding site, and an increase in the expression of the c-Fos and Fra-2 transcription factors.

\section{Materials and methods}

\subsection{Hormones and reagents}

IL-1 $\beta$ was obtained from AbCys (Paris, France). TSH, insulin, transferrin and actinomycin D were obtained from Sigma-Aldrich (Saint-Quentin-Fallavier, France). Forskolin (Fk) and dideoxyforskolin (ddFk) were purchased from Calbiochem EMD Biosciences Inc. (Darmstadt, Germany). 8-CPT-2-O-Me-cAMP (CPT-OMe-cAMP) and 8-CPT-cAMP (CPT-cAMP) were from Biolog (Bremen, Germany), the PKA inhibitor H89 (N-[2-bromocinnamylamino)ethyl]-5-isoquinoline sulfonamide) was from Biomol (Plymouth Meeting, PA). Coon's F12 was from Biochrom AG (Berlin, Germany), and newborn calf serum was from Biowest (Nuaillé, France). Oligonucleotides were from MWG-Biotech (Ebersberg, Germany). pCMV.SPORT$\beta-$ Galactosidase was from Invitrogen (Cergy-Pontoise, France).

\subsection{Cell culture}

The FRTL-5 rat thyroid cell line was a gift from Dr. M. Eggo (Birmingham, UK). Cells were grown to confluence in standard medium composed of Coon's F12 supplemented with $5 \%$ heat-inactivated newborn calf serum, $0.5 \mathrm{mU} / \mathrm{ml}$ bovine TSH, $10 \mu \mathrm{g} / \mathrm{ml}$ insulin and $5 \mu \mathrm{g} / \mathrm{ml}$ transferrin, $2 \mathrm{mM}$ GlutaMAX in a $37^{\circ} \mathrm{C}, 5 \% \mathrm{CO} 2$ incubator. $48 \mathrm{~h}$ before stimulation, cells were incubated in Coon's F12 without serum and hormones (deprivation medium). 


\subsection{Analysis of IL-6 secretion}

After stimulating confluent FRTL-5 cells, the medium $(2 \mathrm{ml})$ was collected as a function of time, centrifuged $\left(20,000 \times \mathrm{g}, 5 \mathrm{~min}, 4^{\circ} \mathrm{C}\right)$ to remove debris, and aliquots were stored at $-80^{\circ} \mathrm{C}$ until analyzed. IL-6 secretion was quantified using a commercially available enzyme-linked immunoassay from Endogen (Rockford, IL).

\subsection{RNA analysis}

Total RNA from confluent FRTL-5 cells was extracted using the RNAble kit (Eurobio, Les Ulis, France) according to the manufacturer's protocol, and analyzed by Northern blot. The rat IL-6 cDNA probe was isolated by RT-PCR using the following primers: sense (5'-CTCTCCGCAAGAGACTTCCA) and antisense (5'TGGTCTTCTGGAGTTCCGTT). Blots were stained with methylene blue, and hybridized with the probes labelled by random priming extension using the Megaprime labelling kit (Amersham GE Healthcare, Orsay, France) and $\left[\alpha^{32} \mathrm{P}\right]$ deoxy-CTP (3000 Ci/mmol) (Perkin-Elmer, Cambridge, UK), as previously described (Pomérance et al., 2003). Membranes were analyzed by quantitative autoradiography using an Instant Imager (Packard Instruments SA, Rungis, France). The IL-6 mRNA levels were normalized by corresponding methylene-blue-stained $18 S$ rRNA, or by stripping the membranes and reprobing with a rat glyceraldehyde-3-phosphate dehydrogenase (GAPDH) CDNA $^{32}$ P-labelled probe.

\subsection{Plasmids}

Luciferase reporter plasmids driven by the wild-type human IL-6 promoter (p1168), the CRE-mutated IL-6 promoter (p1168-mCRE) and the C/EBP-mutated IL-6 promoter (p1168-mC/EBP) were obtained from $\mathrm{Pr}$. G Haegeman, Ghent, Belgium (Vanden Berghe et al., 1998). NFאB-mutated IL-6 promoter luciferase reporter plasmid (p1168-mNFкB) was a gift from Dr. J. Pierre (Châtenay-Malabry, France). The wild type IL-6 promoter was deleted of the AP-1 binding site (p1168$\triangle \mathrm{AP}-1$ ) using a QuickChange Site-Directed Mutagenesis kit (Stratagene, La Jolla, CA) according the manufacturer protocol using the following primers: sense (5'- 
GACATGCCAAAGTGAATAAAAGAAAAAAGAAAGTAAAGG) and antisense (5'CCTTTACTTTCTTTTTTTCTTTTATTCACTTTGGCATGTC). All these plasmids are derived from pGL3-Basic (Promega Corp., Madison, USA). To obtain p(AP-1)6 luciferase plasmid, we ligated six repeats of AP-1 binding element (TGACTAA) in the pLuc-MCS plasmid (Stratagene). The $\mathrm{p}(\mathrm{NF}-\kappa \mathrm{B})_{6}$ luciferase plasmid, containing three copies of the synthetic HIV enhancer oligonucleotide (ACAAGGGACTTTCCGCTGGGGACTTTCCAGGGA), was a gift from Dr. P.A. Bäeuerle (Munich, Germany). The $\mathrm{p}(\mathrm{CRE})_{4}$ luciferase plasmid (AGCCTGACGTCAGAG) was purchased from Stratagene. To generate the pREP4$\beta$-Galactosidase vector ( $p R E P 4-\beta-G A L$ ), pCMV-Sport- $\beta$-Galactosidase was digested at $\mathrm{Kpnl}$ and $\mathrm{Xhol}$ sites, and the $\beta$-Galactosidase insert was ligated in the pREP4 vector (Invitrogen).

\subsection{Transient transfection and luciferase assays}

One day before being transfected, FRTL-5 cells were seeded in 6-well plates and cultured until they reached $70 \%$ confluence. $800 \mathrm{ng}$ of p1168, p1168- $\Delta$ AP-1, p1168-mNF $\kappa B, p 1168-m C / E B P, p(A P-1)_{6}, p(N F \kappa B)_{6}$, or $p(C R E)_{4}$ were cotransfected with 200 ng of pREP4- $\beta-G A L$. Transient transfections were performed in triplicate in standard medium using FuGENE 6 (Roche Applied Science, Meylan, France) according to the manufacturer's protocol. After incubating for 24 hours, cells were cultured in deprivation medium for a further 24h-period. Cells were treated with Fk, TSH, IL-1, or vehicle (0.1\% DMSO) for 7 hours. Luciferase activities were measured using a luciferase assay kit (Roche). Luciferase activities obtained for a given treatment were normalized for $\beta$-galactosidase activities using a $\beta$-galactosidase gene kit (Roche), in order to correct for difference in transfection efficiencies. A synergy index $(\mathrm{SI})$ was defined as the ratio of the relative luciferase activities induced by IL-1 (minus control value) measured in the presence and absence of Fk. A synergy index of 1 indicated that there was no synergy.

\subsection{Cell extracts and western blot analysis}


After stimulation, confluent FRTL-5 cells were washed with ice-cold PBS, and nuclear extracts were prepared as previously described (Corrèze et al., 2005). Cytoplasmic extracts were prepared by sonicating the cells in buffer containing 80 mM $\beta$-glycerophosphate, pH 7.4, 20 mM EGTA, 15 mM MgCl 2 (Pomérance et al., 1996). Proteins were resolved by $12 \%$ SDS-PAGE, transferred onto nitrocellulose membranes, and stained with $3 \%$ Ponceau S. The membranes were saturated with non-fat dry milk for the protein expression studies, or with bovine serum albumin for the protein phosphorylation studies. PKA-phosphorylated proteins were detected using antibodies raised against peptides containing a phospho-Ser/Thr residue with arginine at the -3 position (Cell Signaling Technology, Inc, Beverly, MA). Expression of nuclear proteins was detected using polyclonal antibodies raised against c-Jun, JunD, JunB, Fra-1, Fra-2, FosB, ATF-1 (Santa Cruz Biotechnology, Santa Cruz, CA), CREB, phospho-CREB Ser133, phospho-C-Jun Ser63, phospho-C-Jun Ser73 (Cell Signaling Technology) or c-Fos (Upstate, Lake Placid, NY). Immunoreactive proteins were revealed using a 1:20,000 dilution of anti-rabbit IgG peroxidase conjugate antibody (Promega), and were visualized with Supersignal West Pico reagent (Perbio Science, Vigneux, France). The membranes were stripped and reprobed with either anti-HDAC1 antibody (Santa Cruz Biotechnology) or with $\alpha$-tubulin (Sigma-Aldrich) used as nuclear and cytosolic protein loading controls, respectively.

\subsection{Electrophoretic mobility shift analysis (EMSA)}

EMSAs were carried out using double-stranded oligonucleotides corresponding to the consensus sequence for AP-1 binding site (sense: 5'AAAGTGCTGAGTCACTAATAA, antisense: 5'-TTATTAGTGACTCAGCACTTT) or for CRE binding site (sense: 5'-GCTAAAGGACGTCACCTTAAT, antisense: 5'ATTAAGGTGACGTCCTTTAGC). Oligonucleotides were end-labelled with $\left[\gamma^{32} \mathrm{P}\right]-$ ATP (3000 Ci/mmol) (Perkin-Elmer) and T4 polynucleotide kinase, and then purified with ammonium acetate / ethanol precipitation. Aliquots of nuclear extracts (3 $\mu \mathrm{g}$ protein) were incubated with $0.25 \mathrm{ng}$ of labelled oligonucleotides in $20 \mathrm{mM}$ Hepes $\mathrm{pH}$ 7.9, $2.5 \mathrm{mM} \mathrm{MgCl}_{2}, 3 \mathrm{mM}$ EDTA, $1 \mathrm{mM}$ DTT, 10\% glycerol, $50 \mu \mathrm{M}$ okadaic acid, $1 \mathrm{mM}$ $\mathrm{Na}_{3} \mathrm{VO}_{4}, 1 \mathrm{mM} \mathrm{AEBSF}, 1 \mu \mathrm{g}$ poly $(\mathrm{dl}-\mathrm{dC})$, and a protease inhibitor cocktail in a total volume of $15 \mu \mathrm{l}$. Incubations were carried out at room temperature for $30 \mathrm{~min}$. The 
specificity of binding was determined by adding a 200 -fold excess of unlabelled oligonucleotides. DNA-protein complexes were analyzed on nondenaturing 6\%polyacrylamide gels (Invitrogen) run for 2 hours at $150 \mathrm{~V}$ in a cold room. In the supershift experiments, nuclear extracts were preincubated at room temperature for $60 \mathrm{~min}$ with $1 \mu \mathrm{gg}$ antibodies or non-immune IgG as a control. The gels were fixed, and dried, and then ${ }^{32} \mathrm{P}$ incorporation was revealed and quantified using an Instant Imager (Packard).

\subsection{Statistical analysis}

Results are given as means \pm SEM. Paired Student's $t$-test was used to compare different treatments. $P$ values less than 0.05 were considered significant. The number of culture replicates in a given experiment, and that of independent experiments performed are indicated in the figure legends.

\section{Results}

3.1. IL-6 secretion and gene expression are synergistically induced by IL-1 and Fk in FRTL-5 thyroid cells

The secretion of IL- 6 by FRTL-5 thyroid cells was measured in the culture medium after stimulating by either IL-1 or Fk, a direct activator of adenylyl cyclase, or both. Treating the cells with Fk alone was almost without effect on IL-6 secretion (Fig. 1) whereas IL-1 stimulation induced slow secretion of IL-6. In contrast, when added together, Fk and IL-1 induced a rapid synergistic increase in IL-6 secretion. The maximum IL- 6 secretion rate was observed between the $2^{\text {nd }}$ and $5^{\text {th }}$ hours following stimulation. The amount of IL-6 secreted reached a plateau after $15 \mathrm{~h}(\approx 15 \mathrm{ng}$ IL-6 secreted by $2 \times 10^{6}$ cells), at which time the cells had produced 6 times more IL- 6 than when stimulated by IL-1 alone. At this time, TSH $(1 \mathrm{mU} / \mathrm{ml})$ also synergistically increased IL-1-induced IL-6 production ( $\approx 15 \mathrm{ng} / 2 \times 10^{6}$ cells, results not shown). However, TSH alone increased IL-6 production $\left(2.4 \mathrm{ng} / 2 \times 10^{6}\right.$ cells) whereas the effect of Fk was below the detection limit. 
To determine whether the synergistic effect of Fk on IL-1-stimulated IL-6 secretion was due to changes in the level of IL-6 mRNA, Northern blot analysis were carried out on FRTL-5 cell RNA using IL-6 and GAPDH radiolabelled cDNA probes. Two IL-6 mRNAs of 1.2 and $2.4 \mathrm{~kb}$ were detected in cells stimulated with either Fk or $\mathrm{IL}-1$ alone, or in combination (Fig. 2A). The two transcripts were induced by the different stimulations following a similar pattern. The quantification of the 1.2- and 2.4-kb forms of IL-6 mRNA, relative to GAPDH mRNA, is shown in figures $2 \mathrm{~B}$ and $2 \mathrm{C}$, respectively. The amounts of the two IL- 6 mRNAs increased sharply after $1 \mathrm{~h}$ of treatment by IL-1 plus Fk, compared to treatment with IL-1 alone (mean value $\approx 3.2$ fold) or $\mathrm{Fk}$ alone (mean value $\approx 4.5$-fold). The maximum synergistic effect was obtained after stimulating with IL-1 plus Fk for $2 \mathrm{~h}$, by which time the mRNA levels measured in the presence of IL-1 alone had almost returned to the basal level. Then, the increase produced by the combination of IL-1 plus Fk was more than 10-fold greater than that produced by IL-1 alone. The 1.2-kb mRNA species was then 4 times more abundant than the 2.4-kb form. Thereafter, the amounts of both mRNA forms declined.

3.2. The CAMP/PKA pathway is involved in the synergistic effect of Fk on IL-1stimulated IL-6 mRNA expression

To find out whether the synergistic effect of Fk on IL-1-stimulated IL-6 mRNA expression involved the cAMP pathway, FRTL-5 cells were treated with IL-1 either alone or in combination with $\mathrm{Fk}$, dideoxyforskolin (ddFK), a structural analog of $\mathrm{Fk}$ that does not activate adenylyl cyclase, or CPT-cAMP, a cell-permeable analogue of cAMP. Northern blot analysis (Fig. 3A) showed that, in contrast to Fk, ddFk had no effect on IL-1-stimulated IL-6 mRNA expression, whereas CPT-cAMP exerted a synergistic effect similar to that of Fk.

Since cAMP produces many of its biological effects by activating PKA, cells were preincubated with $\mathrm{H} 89$, a compound that blocks the ATP binding site of PKA, before stimulation by IL-1 plus Fk. Figure 3B shows that $\mathrm{H} 89$ decreased the IL-1/Fkinduced IL-6 mRNA expression by $\approx 50 \%$. To confirm the impact of $\mathrm{H} 89$ on PKA activity, cell extracts were analyzed by Western blot using an antibody specifically directed against a PKA-phosphorylated motif. Figure 3C shows that H89 partially inhibited the PKA activity enhanced by the treatment with IL-1 plus Fk. We also 
checked that IL-1 had no effect on the CAMP/PKA pathway (result not shown). We investigated whether the exchange factor EPAC, which is known to be directly activated by cAMP, could be implicated in the synergistic effect of cAMP. Northern blot analysis shown in Figure 3D indicated that CPT-OMe-CAMP, a specific activator of EPAC but not of PKA, had no effect by itself on IL-6 mRNA expression, and in contrast to CPT-cAMP did not increase the effect of IL-1.

\section{3. cAMP induces stabilization of IL-6 mRNA in FRTL-5 cells}

To find out whether the synergistic effect of Fk on IL-1-stimulated IL-6 mRNA expression resulted from an alteration in IL-6 mRNA stability, we performed an mRNA stability assay by Northern blot analysis. FRTL- 5 cells were stimulated with Fk plus IL-1 for 90 min to induce IL-6 mRNA. Actinomycin D, an inhibitor of overall gene transcription, was then added in the absence or presence of $\mathrm{Fk}$ or IL-1, alone or in combination, and mRNA levels were measured as a function of time.

Figure 4 shows that in both unstimulated and IL-1-treated FRTL-5 cells, the level of $1.2 \mathrm{~kb}$ IL-6 transcript decreased similarly in a time-dependent manner (40\% of the mRNA remained after $60 \mathrm{~min}$ ). A significant stabilization of IL-6 mRNA was observed in the presence of $\mathrm{Fk}$ alone ( $90 \%$ of the mRNA remained after $60 \mathrm{~min}$ ), or in combination with IL-1, although IL-1 significantly decreased the stabilizing effect of Fk (65\% mRNA remained after $60 \mathrm{~min})$. Similar results were found for the $2.4 \mathrm{~kb}$ IL- 6 transcript (not shown).

3.4. The IL-1-induced IL-6 promoter activity is stimulated synergistically via the cAMP/PKA pathway

To examine whether the synergistic effect of Fk and IL-1 also occurred at the level of IL-6 gene transcription, reporter gene experiments were performed. FRTL-5 cells were transiently transfected with a luciferase reporter plasmid containing the 1.2-kb regulatory 5 '-region of the human IL-6 gene (p1168). They were serum- and hormone-starved, and stimulated by IL-1 or/and by agonists of the CAMP/PKA pathway. Typical results are shown in Fig. 5A. Treatment with Fk caused a moderate, 1.9-fold induction of luciferase expression. whereas TSH caused a 5.9-fold inducton. IL-1 increased IL-6 promoter activity 10-fold, and when Fk or TSH were combined 
with IL-1, the IL-6 promoter activity was strongly stimulated 40- and 35-fold, respectively. This synergistic effect was reproducible, and the average of 18 independent experiments clearly indicated the minor effect of Fk on luciferase activity (1.5-fold induction \pm 0.2 ), the marked effect of IL-1 (8.7-fold induction \pm 1.8 ), and the synergistic effect of IL-1 plus Fk (24-fold induction \pm 5 ), corresponding to a significant $(P<0.0005$, paired Student's $t$-test) 2.8-fold enhancement relative to IL-1 alone.

We hypothesized that the synergistic effect of Fk on IL-1 at the transcriptional level might require the activation of PKA, as suggested by its involvement in the regulation of IL-6 mRNA levels. To test this possibility, we preincubated p1168transfected cells with $\mathrm{H} 89$, and then stimulated them by $\mathrm{Fk}$ or IL-1, separately or in combination. Figure 5B shows that treatment with $\mathrm{H} 89$ reduced the synergistic effect of Fk on IL-1-induced IL-6 promoter activity by $\approx 65 \%$. Taken together, these data indicate that synergistic cooperation occurs between the cAMP/PKA and IL-1 signalling pathways to up-regulate IL-6 promoter activity in FRTL-5 thyroid cells.

\subsection{The AP-1 and CRE response element mediated the synergistic effect of cAMP} on IL-1 stimulated IL-6 promoter activity

Since it has been reported that IL-1 exerts its effects on IL-6 promoter mainly by inducing the activation of $A P-1, C R E, C / E B P$ and NF- $k B$, we searched for the cisregulatory sequences that could be responsible for the synergistic effect of $\mathrm{Fk}$ by IL-1. FRTL-5 cells were transiently transfected with the p1168 plasmid either wildtype, or deleted of the AP-1 binding site (p1168- $\triangle A P 1)$, or point-mutated in CRE

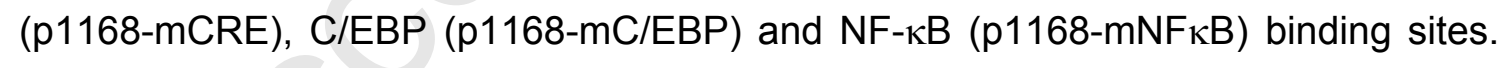
Cells were then treated with IL-1 or IL-1 plus Fk. Figure 6A shows that deleting the $\mathrm{AP}-1$ site reduced the response to IL-1, and that the synergy index ( $\mathrm{SI})$, as defined in the "Materials and Methods" section, was reduced from 3.1 to 1.3. Inactivation of the CRE site also resulted in a marked decrease in the SI (1.5), whereas mutation of the $\mathrm{C} / \mathrm{EBP}$ binding site had a weaker effect. Mutation of the NF-kB binding site considerably diminished the response to IL-1, whereas the synergistic effect of Fk appeared to be conserved.

To confirm the role of the AP-1 and CRE sites in the Fk/IL-1 synergistic effect, synthetic reporter gene constructs were transfected. Figure $6 \mathrm{~B}$ shows that IL-1 strongly activated the $\mathrm{p}(\mathrm{NF} \kappa \mathrm{B})_{6}$ construct, but that the synergistic effect of Fk was 
low. Conversely, IL-1 weakly activated the $\mathrm{p}(\mathrm{AP} 1)_{6}$ construct, and the synergistic effect of Fk ( $\mathrm{SI}=4.2)$ was similar to that obtained with the p1168-IL6 construct. Using the $\mathrm{p}(\mathrm{CRE})_{4}$ construct, the synergy index reached $\approx 2$. Taken together, these findings indicate that the AP-1 binding site was essential to mediate the enhancement by Fk of the IL-1-induced IL-6 promoter activity, but that the CRE could also be involved in this effect.

To investigate the synergy mechanisms, nuclear extracts obtained from FRTL-5 cells, either untreated or treated with $\mathrm{Fk}, \mathrm{IL}-1$, or $\mathrm{Fk} / \mathrm{IL}-1$, were incubated with a ${ }^{32} \mathrm{P}$-radiolabelled oligonucleotide containing the AP-1 and CRE sequences of the rat IL-6 promoter. Figure 7A shows a typical autoradiogram obtained from gel shift assays. Binding of the AP-1 radiolabelled probe to nuclear proteins was not altered by Fk, whereas it was increased by IL-1 and more enhanced by both IL-1 and Fk. An excess of unlabelled oligonucleotide prevented the binding of the radiolabelled probe to nuclear proteins, indicating that the binding mechanism was saturable, whereas non-specific binding was not affected. The saturable binding, quantified in five independent experiments, was increased 1.9 -fold \pm 0.3 by IL- 1 and 2.7 -fold \pm 0.4 by IL-1 plus FK, corresponding to a significant $(P<0.05$, paired Student's $t$-test $)$ enhancement relative to IL-1 alone. Incubation of nuclear extracts with the CRE oligonucleotide resulted in the formation of a complex, the intensity of which did not change as a function of the treatments to which the cells were exposed (Figure 7B). No increase was found using radiolabelled probes containing the C/EBP and NF- $\mathrm{BB}$ binding sites (not shown). Competition analysis with unlabelled oligonucleotide demonstrated the specificity of the binding.

Antibodies to the Jun family of transcription factors (c-Jun, JunB, JunD) decreased the binding of the AP-1 probe to nuclear proteins from IL-1- and IL-1/Fktreated cells, and supershifted the bound probe (Fig. 7C). Antibodies against the Fos family of transcription factors decreased strongly the binding of the AP-1 probe to nuclear proteins in IL-1- and IL-1/Fk treated cells. A strong supershift was induced using antibodies against FosB. In contrast, antibodies against Fra-1 was without effect (Fig. 7C).

3.6. cAMP increases expression of c-Fos and Fra-2 transcription factors stimulated by IL-1 
The results described above indicate that the binding of the AP-1 oligonucleotide probe to the AP-1 family of transcription factors was synergically enhanced by Fk and IL-1. We therefore used Western blotting to investigate the expression and phosphorylation of these factors in nuclear extracts of FRTL-5 cells in response to $\mathrm{Fk}$ and $\mathrm{IL}-1$, alone or in combination. Figure $8 \mathrm{~A}$ shows that treatment with IL-1 plus Fk produced a markedly greater expression of c-Fos and Fra-2 than treatment with IL-1 alone. In contrast, FosB and Fra-1 were not induced by Fk and/or IL-1. Among the Jun family members, the expression of JunD expression was unaffected by the treatments. C-Jun and JunB was markedly induced by IL-1, but Fk had no effect. To investigate the possible role of Jun activation, we performed Western blot analysis using antibodies raised against c-Jun phosphorylated on Ser63 or Ser73. The latter antibody also recognizes JunD phosphorylated on Ser100. IL-1 increased phosphorylated c-Jun in parallel with total c-jun, so that the ratio of phosphorylated to total protein may not be changed. In contrast, IL-1 induced phosphorylation of JunD (Ser100). None of these effects were enhanced by Fk (Fig. 8A).

Since we observed that mutation of the CRE site in the IL-6 promoter reduced the synergistic effect of Fk, we studied the expression of CREB and ATF-1 in response to Fk and IL-1, alone or in combination. No change in CREB or ATF-1 expression was observed (Fig. 8B). Phosphorylation of CREB at Ser133, and of ATF-1 at Ser63, is generally accepted as being a key event in the regulation of transcription. Figure $8 \mathrm{~B}$ shows that phosphorylations of $\mathrm{CREB}$ and $\mathrm{ATF}-1$ were induced by $\mathrm{Fk}$ and $\mathrm{IL}-1$. However, their combination did not trigger significant synergy.

\section{Discussion}

In this report, we describe the synergistic effect exerted by cAMP-elevating agents on IL-1-induced secretion and gene expression of IL- 6 in FRTL-5 thyroid cells, and we identify some mechanisms involved in this effect. It has been reported that IL-1 enhances IL-6 production in human and in FRTL-5 thyroid cells (Diamant et al., 1991), and that IL-1 and TSH act synergistically to induce IL-6 production in FRTL-5 
cells (Iwamoto et al., 1991). However, these studies did not address the question of whether the changes in IL-6 expression occurred at the transcriptional or posttranscriptional level, nor what molecular mechanisms were involved in the synergistic effect of IL-1 and TSH. In the present work, we report that Fk, which mimics the action of TSH on CAMP production, also greatly enhanced the secretion of IL-6 induced by IL-1, whereas it had almost no effect by itself. However, TSH alone moderately induced IL-6 expression. This may be due to contaminants that are present in TSH preparations and that activate ERK signalling pathways in a TSH receptor-independent manner, as has previously been reported (Corrèze et al., 2000). The amount of IL-6 secreted in response to the combined stimulation by IL-1 and Fk was of the same order of magnitude as that reported using cultured human thyrocytes obtained from patients with Graves' disease (Weetman et al., 1990).

Enhanced IL-6 secretion was probably related to an increase in IL-6 mRNA levels. We show that Fk and IL-1 did indeed act synergistically to increase the expression of the 1.2- and 2.4-kb IL-6 transcripts, and that the effect of Fk was cAMP-mediated. The transient nature of this effect suggests that the IL-6 gene is under stringent regulatory control in thyroid cells. Two independent pathways involving either PKA or EPAC, can be activated in cells by cAMP (De Rooij et al., 1998). For example, it has recently been reported that EPAC is involved in IL-6 release in response to activation of the $\beta_{2}$-adrenergic receptor in the RAW murine macrophage cell line (Tan et al., 2007). In FRTL-5 cells, we demonstrated that EPAC was not implicated in the synergistic effect of cAMP on IL-1 stimulated IL-6 mRNA expression. In contrast, using the selective PKA inhibitor H89, we showed that the cAMP/PKA pathway was involved.

IL-6 gene expression is known to be regulated at the transcriptional or posttranscriptional level, or both (Vanden Berghe, 2000 ; Elias and Lentz, 1990 ; Miyazawa et al, 1998 ; Winzen et al, 1999). Here, we show that the stability of the two IL-6 mRNA species in FRTL-5 cells was enhanced to a greater extent in the presence of Fk plus IL-1 than by IL-1 alone, although Fk alone exerted a more marked stabilization effect. PEPCK mRNA has been reported to be stabilized by cAMP/PKA in kidney cells (Dhakras et al., 2006), and TSH has been reported to be involved in stabilizing c-myc mRNA in dog thyroid cells (Pirson et al., 1996). However, as far as we are aware, this is the first report of a stabilizing effect of cAMP on IL-6 mRNA. 
The AU-rich elements (AREs) in the 3'-untranslated region (UTR) of some mRNAs contribute to regulation of gene expression by affecting mRNA stability (Shim and Karin, 2002). The two rat IL-6 mRNA species differ by the length of their 3'nontranslated region (Northemann et al., 1989), but this is without consequence for the relative stability of these transcripts under the experimental conditions of the present study. It has been shown that the p38 MAPK/MK2 pathway is involved in regulating mRNA stability via AREs in the 3'-UTR of IL-6 mRNA (Mahtani et al., 2001; Neininger et al., 2002). Although IL-1 activated strongly p38-MAPK phosphorylation in FRTL-5 cells (unpublished data), IL-1 did not stabilize IL-6 mRNA, suggesting that other mechanisms were involved.

In addition to the post-transcriptional mechanism related to IL-6 mRNA stability, we report that IL-6 promoter activity is also involved in the synergistic effect of cAMP on IL-1-stimulated IL-6 expression in FRTL-5 cells. A synergistic effect of CAMP on LPS- or IL-1-stimulated IL-6 promoter activity has been documented in mesangial cells (Grassl et al., 1999) and in Caco-2 cells (Hershko et al., 2002). In FRTL-5 cells, we show that cAMP exerts its synergistic effect on IL-1-stimulated IL-6 promoter activity by a mechanism involving PKA, in agreement with that regulating IL-6 mRNA expression. Using various promoter constructs containing deleted or mutated transcription factor binding sites, we show that the AP-1 and CRE sites were mainly involved in the synergistic effect of CAMP on IL-1-stimulated IL-6 promoter activity. We confirmed these data using synthetic reporter gene constructs containing consensus AP-1 binding sites or consensus CRE sites cloned upstream of the luciferase reporter gene. Although the NFKB binding site was not involved in the synergistic effect, it was required for the induction of promoter activity by IL-1 or IL-1/FK. These results are different in some respects from those obtained in Caco2 cells, where the binding sites for NF-KB, C/EBP, CREB and AP-1 were all involved in this synergistic effect (Hershko et al., 2002), indicating that the mechanisms differ from one cell type to another. Our electrophoretic mobility shift assays indicated that only the binding of the AP-1 radiolabelled probe to proteins observed in the presence of IL-1 was enhanced by treating the FRTL-5 cells with Fk. No such increase occurred when probes corresponding to the other IL-6 promoter binding sites were used. In other cell types, similar experiments have been performed with varying results. In mesangial cells, cAMP also increased the binding of an AP-1 probe, but it 
inhibited that of a NF-kB probe, and had no effect on that of a C/EBP probe (Grassl et al., 1999). These authors found that a constitutive DNA-protein complex was formed between mesangial nuclear proteins and a CRE oligonucleotide. We also found a constitutive complex between FRTL-5 nuclear proteins and a CRE oligonucleotide, but in this case, binding did not depend on the stimulation used. These discrepancies between different cell types suggest that the effects of cAMP on transcription factors regulating the IL-6 gene are cell specific.

To identify the transcription factors responsible for the enhancement of AP-1 oligonucleotide binding by CAMP, we performed supershift experiments. Antibodies against c-Jun, JunB, JunD, Fra-2, c-Fos and FosB decreased the binding of nuclear proteins from Fk/IL-1-treated cells and/or induced a supershift. Therefore, the AP-1 complex in Fk/IL-1-treated FRTL-5 cells could contain all these proteins. However, only the expression of c-Fos and Fra-2 proteins was boosted by treating cells with IL-1 plus FK, a result that could account for the increase in both AP-1 oligonucleotide binding and IL-6 promoter activity. c-Fos mRNA has already been shown to be induced by TSH and cAMP in FRTL-5 (Tramontano et al., 1986 ; Isozaki and Kohn, 1987 ) and dog (Deleu et al., 1999) thyroid cells. To the best of our knowledge, this is the first report of the induction of c-Fos by IL-1 in thyroid cells, or by cAMP plus IL-1 regardless of the cell type. However, the mechanism of the synergistic effect of FK and IL-1 on C-Fos expression reported in the present work remains to be identified.

Our gene reporter assays suggest that the CRE site of the IL-6 promoter could be involved in the synergistic effect, as has also been suggested for other cell types (Grassl et al., 1999 ; Hershko et al., 2002). However, CREB/ATF-1 expression was not altered by IL-1 plus FK, and we did not observe any significant synergistic effect on CREB/ATF-1 phosphorylation. We may suggest that CREB/ATF-1, which is constitutively expressed and bound to the CRE site, and which is phosphorylated in response to $\mathrm{Fk}$ as well as to $\mathrm{IL}-1$, may play an enhancing role in activating the IL-6 promoter by Fk/IL-1, without being responsible per se for the synergistic effect.

The role of IL-6 has not been fully elucidated in thyroid tissues. IL-6 is a multifunctional cytokine with key roles in promoting B-cell proliferation, and in the differentiation and activation of T-cells (Kishimoto et al., 2006). This means that IL-6 may exert paracrine effects on immune cells infiltrating the thyroid gland in the course of autoimmune thyroid diseases. These effects could be amplified, due to the synergy between TSH or TSAb (both of which stimulates the cAMP pathway) and IL-1 on IL-6 
production. IL-6 could also exert autocrine effects on thyrocytes themselves. We have observed that IL-6 receptor is expressed in FRTL-5 cells, and that the STAT-3 transcription factor is rapidly phosphorylated in response to IL-6 (unpublished data). Expression of IL-6 and of IL-6 receptors has been reported to vary in different forms of diseased thyroid tissues. In one study, IL-6 expression was detected by immunohistochemistry in $100 \%$ of cases of Graves' disease or Hashimoto thyroiditis (Ruggeri et al., 2002). Furthermore, the IL-6 receptor is frequently expressed in follicular cells in Graves' disease, suggesting that the IL-6 signalling pathway may be actively involved in this disorder. Conventional papillary thyroid carcinomas, but not follicular or anaplastic thyroid carcinomas, express IL-6, IL-6 receptor, and STAT-3 (Trovato et al., 2003). Accordingly, it has been recently suggested that the IL6/STAT-3 signalling pathway can up-regulate Wnt5a expression in a papillary thyroid carcinoma cell line, and that the non-canonical Wnt5a pathway may modulate cell adhesion and motility (McCall et al., 2007).

In conclusion, the present study has demonstrated that the cAMP/PKA pathway increases the IL-1-dependent production of IL-6 in FRTL-5 thyroid cells by mechanisms involving the stability of IL- 6 mRNA, the AP-1 binding site of the IL- 6 gene promoter, and c-Fos and Fra-2 transcription factor expression. Elucidating the specific signalling mechanisms by which IL-1 and TSH/CAMP synergistically regulate IL-6 secretion by thyroid cells may provide some insight into the biological mechanisms which modify inflammatory processes in thyroid autoimmune disorders. 


\section{Acknowledgements}

We would like to mention the excellent technical contribution of Françoise Chantoux. We are grateful to Josiane Pierre and Guy Haegeman for their kind gift of IL-6 promoter constructs. 


\section{References}

Akira, S., Isshiki, H., Sugita, T., Tanabe, O., Kinoshita, S., Nishio, Y., Nakajima, T., Hirano, T. and Kishimoto, T., 1990. A nuclear factor for IL-6 expression (NF-IL6) is a member of a C/EBP family. Embo J. 9, 1897-1906.

Aust, G. and Scherbaum, W.A., 1996. Expression of cytokines in the thyroid: thyrocytes as potential cytokine producers. Exp. Clin. Endocrinol. Diabetes 104 Suppl 4, 64-67.

Correze, C., Blondeau, J.P. and Pomerance, M., 2000. The thyrotropin receptor is not involved in the activation of p42/p44 mitogen-activated protein kinases by thyrotropin preparations in Chinese hamster ovary cells expressing the human thyrotropin receptor. Thyroid 10, 747-752.

Correze, C., Blondeau, J.P. and Pomerance, M., 2005. p38 mitogen-activated protein kinase contributes to cell cycle regulation by CAMP in FRTL-5 thyroid cells. Eur. J. Endocrinol. 153, 123-133.

de Rooij, J., Zwartkruis, F.J., Verheijen, M.H., Cool, R.H., Nijman, S.M., Wittinghofer, A. and Bos, J.L., 1998. Epac is a Rap1 guanine-nucleotide-exchange factor directly activated by cyclic AMP. Nature 396, 474-477.

Deleu, S., Pirson, I., Clermont, F., Nakamura, T., Dumont, J.E. and Maenhaut, C., 1999. Immediate early gene expression in dog thyrocytes in response to growth, proliferation, and differentiation stimuli. J. Cell. Physiol. 181, 342-354.

Dendorfer, U., Oettgen, P. and Libermann, T.A., 1994. Multiple regulatory elements in the interleukin- 6 gene mediate induction by prostaglandins, cyclic AMP, and lipopolysaccharide. Mol. Cell. Biol. 14, 4443-4454.

Dhakras, P.S., Hajarnis, S., Taylor, L. and Curthoys, N.P., 2006. cAMP-dependent stabilization of phosphoenolpyruvate carboxykinase mRNA in LLC-PK1-F+ kidney cells. Am. J. Physiol. Renal Physiol. 290, F313-318.

Diamant, M., Kayser, L., Rasmussen, A.K., Bech, K. and Feldt-Rassmussen, U., 1991. Interleukin-6 production by thyroid epithelial cells. Enhancement by interleukin-1. Autoimmunity 11, 21-26.

Elias, J.A. and Lentz, V., 1990. IL-1 and tumor necrosis factor synergistically stimulate fibroblast IL-6 production and stabilize IL-6 messenger RNA. J Immunol 145, 161-166. 
Grassl, C., Luckow, B., Schlondorff, D. and Dendorfer, U., 1999. Transcriptional regulation of the interleukin-6 gene in mesangial cells. J Am Soc Nephrol 10, 1466-1477.

Grubeck-Loebenstein, B., Buchan, G., Chantry, D., Kassal, H., Londei, M., Pirich, K., Barrett, K., Turner, M., Waldhausl, W. and Feldmann, M., 1989. Analysis of intrathyroidal cytokine production in thyroid autoimmune disease: thyroid follicular cells produce interleukin-1 alpha and interleukin-6. Clin. Exp. Immunol. 77, 324-330.

Hershko, D.D., Robb, B.W., Luo, G. and Hasselgren, P.O., 2002. Multiple transcription factors regulating the IL-6 gene are activated by CAMP in cultured Caco-2 cells. Am. J. Physiol. Regul. Integr. Comp. Physiol. 283, R1140-1148.

Hirano, T., Akira, S., Taga, T. and Kishimoto, T., 1990. Biological and clinical aspects of interleukin 6. Immunol. Today 11, 443-449.

Isozaki, O. and Kohn, L.D., 1987. Control of c-fos and c-myc proto-oncogene induction in rat thyroid cells in culture. Mol. Endocrinol. 1, 839-848.

Iwamoto, M., Sakihama, T., Kimura, N., Tasaka, K. and Onaya, T., 1991. Augmented interleukin 6 production by rat thyrocytes (FRTL5): effect of interleukin 1 beta and thyroid-stimulating hormone. Cytokine 3, 345-349.

Kambe, F., Miyazaki, T. and Seo, H., 1996. Differential induction of fos and jun family genes by thyrotropin in rat thyroid FRTL-5 cells. Thyroid 6, 123-128.

Kennedy, R.L., Jones, T.H., Davies, R., Justice, S.K. and Lemoine, N.R., 1992. Release of interleukin- 6 by human thyroid epithelial cells immortalized by simian virus 40 DNA transfection. J. Endocrinol. 133, 477-482.

Kikumori, T., Kambe, F., Nagaya, T., Funahashi, H. and Seo, H., 2001. Thyrotropin modifies activation of nuclear factor kappaB by tumour necrosis factor alpha in rat thyroid cell line. Biochem. J. 354, 573-579.

Kishimoto, T., 2006. Interleukin-6: discovery of a pleiotropic cytokine. Arthritis Res. Ther. 8 Suppl 2, S2.

Libermann, T.A. and Baltimore, D., 1990. Activation of interleukin-6 gene expression through the NF-kappa B transcription factor. Mol. Cell. Biol. 10, 2327-2334.

Mahtani, K.R., Brook, M., Dean, J.L., Sully, G., Saklatvala, J. and Clark, A.R., 2001. Mitogen-activated protein kinase p38 controls the expression and posttranslational modification of tristetraprolin, a regulator of tumor necrosis factor alpha mRNA stability. Mol Cell Biol 21, 6461-6469. 
McCall, K.D, Harii, N., Lewis, C.J., Malgor, R., Kim, W.B., Saji, M., Kohn, A.D., Moon, R.T., and Kohn, L.D., 2007. High Basal Levels of Functional Toll-Like Receptor 3 (TLR3) and Non-Cannonical Wnt5a Are Expressed in Papillary Thyroid Cancer (PTC) and Are Coordinately Decreased by Phenylmethimazole Together with Cell Proliferation and Migration. Endocrinology 148, 4226-4237.

Miyazawa, K., Mori, A., Miyata, H., Akahane, M., Ajisawa, Y. and Okudaira, H., 1998. Regulation of interleukin-1beta-induced interleukin- 6 gene expression in human fibroblast-like synoviocytes by p38 mitogen-activated protein kinase. J. Biol. Chem. 273, 24832-24838.

Neininger, A., Kontoyiannis, D., Kotlyarov, A., Winzen, R., Eckert, R., Volk, H.D., Holtmann, H., Kollias, G. and Gaestel, M., 2002. MK2 targets AU-rich elements and regulates biosynthesis of tumor necrosis factor and interleukin-6 independently at different post-transcriptional levels. J. Biol. Chem. 277, 30653068.

Northemann, W., Braciak, T.A., Hattori, M., Lee, F. and Fey, G.H., 1989. Structure of the rat interleukin 6 gene and its expression in macrophage-derived cells. J. Biol. Chem. 264, 16072-16082.

Pasare, C. and Medzhitov, R., 2003. Toll pathway-dependent blockade of CD4+CD25+ T cell-mediated suppression by dendritic cells. Science 299, 10331036.

Pirson, I., Coulonval, K., Lamy, F. and Dumont, J.E., 1996. c-Myc expression is controlled by the mitogenic cAMP-cascade in thyrocytes. J. Cell. Physiol. 168, 59-70.

Pomerance, M., Carapau, D., Chantoux, F., Mockey, M., Correze, C., Francon, J. and Blondeau, J.P., 2003. CCAAT/enhancer-binding protein-homologous protein expression and transcriptional activity are regulated by 3',5'-cyclic adenosine monophosphate in thyroid cells. Mol. Endocrinol. 17, 2283-2294.

Pomerance, M., Thang, M.N., Tocque, B. and Pierre, M., 1996. The Ras-GTPaseactivating protein $\mathrm{SH} 3$ domain is required for $\mathrm{Cdc} 2$ activation and mos induction by oncogenic Ras in Xenopus oocytes independently of mitogen-activated protein kinase activation. Mol. Cell. Biol. 16, 3179-3186.

Ruggeri, R.M., Barresi, G., Sciacchitano, S., Trimarchi, F., Benvenga, S. and Trovato, M., 2006. Immunoexpression of the CD30 ligand/CD30 and IL-6/IL-6R signals in thyroid autoimmune diseases. Histol. Histopathol. 21, 249-256. 
Shim, J. and Karin, M., 2002. The control of mRNA stability in response to extracellular stimuli. Mol. Cells 14, 323-331.

Simons, P.J., Delemarre, F.G. and Drexhage, H.A., 1998. Antigen-presenting dendritic cells as regulators of the growth of thyrocytes: a role of interleukin1 beta and interleukin-6. Endocrinology 139, 3148-3156.

Simons, P.J., Delemarre, F.G., Jeucken, P.H. and Drexhage, H.A., 1998. Preautoimmune thyroid abnormalities in the biobreeding diabetes-prone (BB-DP) rat: a possible relation with the intrathyroid accumulation of dendritic cells and the initiation of the thyroid autoimmune response. J. Endocrinol. 157, 43-51.

Tan, K.S., Nackley, A.G., Satterfield, K., Maixner, W., Diatchenko, L. and Flood, P.M., 2007. Beta2 adrenergic receptor activation stimulates pro-inflammatory cytokine production in macrophages via PKA- and NF-kappaB-independent mechanisms. Cell. Signal. 19, 251-260.

Tanabe, O., Akira, S., Kamiya, T., Wong, G.G., Hirano, T. and Kishimoto, T., 1988. Genomic structure of the murine IL-6 gene. High degree conservation of potential regulatory sequences between mouse and human. J. Immunol. 141, 3875-3881.

Todd, I., Pujol-Borrell, R., Hammond, L.J., McNally, J.M., Feldmann, M. and Bottazzo, G.F., 1987. Enhancement of thyrocyte HLA class II expression by thyroid stimulating hormone. Clin. Exp. Immunol. 69, 524-531.

Tramontano, D., Chin, W.W., Moses, A.C. and Ingbar, S.H., 1986. Thyrotropin and dibutyryl cyclic AMP increase levels of c-myc and c-fos mRNAs in cultured rat thyroid cells. J. Biol. Chem. 261, 3919-3922.

Trovato, M., Grosso, M., Vitarelli, E., Ruggeri, R.M., Alesci, S., Trimarchi, F., Barresi, G., and Benvenga, S., 2003. Distinctive expression of STAT3 in papillary thyroid carcinomas and a subset of follicular adenomas. Histol Histopathol. 18, 393399.

Vanden Berghe, W., Plaisance, S., Boone, E., De Bosscher, K., Schmitz, M.L., Fiers, W. and Haegeman, G., 1998. p38 and extracellular signal-regulated kinase mitogen-activated protein kinase pathways are required for nuclear factorkappaB p65 transactivation mediated by tumor necrosis factor. J. Biol. Chem. 273, 3285-3290.

Vanden Berghe, W., Vermeulen, L., De Wilde, G., De Bosscher, K., Boone, E. and Haegeman, G., 2000. Signal transduction by tumor necrosis factor and gene 
regulation of the inflammatory cytokine interleukin-6. Biochem. Pharmacol. 60, 1185-1195.

Weetman, A.P. and McGregor, A.M., 1994. Autoimmune thyroid disease: further developments in our understanding. Endocr. Rev. 15, 788-830.

Weetman, A.P., Bright-Thomas, R. and Freeman, M., 1990. Regulation of interleukin6 release by human thyrocytes. J. Endocrinol. 127, 357-361.

Winzen, R., Kracht, M., Ritter, B., Wilhelm, A., Chen, C.Y., Shyu, A.B., Muller, M., Gaestel, M., Resch, K. and Holtmann, H., 1999. The p38 MAP kinase pathway signals for cytokine-induced mRNA stabilization via MAP kinase-activated protein kinase 2 and an AU-rich region-targeted mechanism. Embo J. 18, 49694980. 


\section{Figure legends}

Fig. 1: Effects of IL-1 and Fk on IL-6 secretion. FRTL-5 cells were cultured to confluence in standard medium, and then incubated for $48 \mathrm{~h}$ in deprivation medium. Cells $\left(2 \times 10^{6}\right.$ cells) were treated with $10 \mu \mathrm{M} \mathrm{Fk}(\square), 40 \mathrm{ng} / \mathrm{ml} \mathrm{IL-1}(\mathbf{\Delta})$, or both $(\mathbf{O})$, for the times indicated (h). After the indicated treatment times, the IL-6 concentration in the culture medium was determined by ELISA. Similar results were obtained in three independent experiments.

Fig. 2: Effects of IL-1 and Fk on IL-6 mRNA expression. FRTL-5 cells were cultured to confluence in standard medium, and then incubated for $48 \mathrm{~h}$ in deprivation medium. Cells were stimulated with $10 \mu \mathrm{M} \mathrm{Fk}, 40 \mathrm{ng} / \mathrm{ml} \mathrm{IL-1}$, or both, for the times indicated. Total RNA was analyzed by Northern blot, and IL-6 mRNA transcripts were detected by hybridization with a specific ${ }^{32} \mathrm{P}$-labelled cDNA probe and quantitative autoradiography. (A) Autoradiograms of the IL-6 transcripts (upper panel) and of the GAPDH transcript, analyzed as a loading control (lower panel). (B) Quantification of the 1.2-kb IL-6 mRNA and (C) of the 2.4-kb IL-6 mRNA, corrected for the relative expression of GAPDH mRNA. Three independent experiments gave similar results.

Fig. 3: Involvement of cAMP signalling pathways in the expression of IL-6 mRNAs. Confluent FRTL-5 cells were pretreated, or not, for $2 \mathrm{~h}$ without or with $10 \mu \mathrm{M}$ of the PKA inhibitor H89, as indicated. The cells were stimulated for 90 min with $40 \mathrm{ng} / \mathrm{ml}$ IL-1, $10 \mu \mathrm{M}$ Fk, $10 \mu \mathrm{M}$ ddFk, $100 \mu \mathrm{M}$ CPT-cAMP, $100 \mu \mathrm{M}$ CPT-OMe-cAMP, alone or in combination, as indicated. (A), (B), (D) IL-6 mRNAs were detected by Northern blot, using a specific ${ }^{32} \mathrm{P}$-labeled cDNA and autoradiography (upper panels). The corresponding methylene-blue stained 18S rRNA bands are shown as loading controls (lower panels). (C): equal amounts of proteins from cytoplasmic extracts were analyzed by Western blot using antibodies for phospho-PKA substrates (upper panel). Alpha-tubulin was used as a loading control (lower panel). Similar results were obtained in two independent experiments.

Fig. 4: Effect of IL-1 and/or Fk on IL-6 mRNA stability. FRTL-5 cells were prestimulated for $90 \mathrm{~min}$ with $40 \mathrm{ng} / \mathrm{ml} \mathrm{IL-1}$ plus $10 \mu \mathrm{M} \mathrm{Fk}$, then the medium was 
changed and replaced by $5 \mu \mathrm{g} / \mathrm{ml}$ actinomycin $D$ either alone $(O)$, or in the presence of IL-1 $(\mathbf{\Delta})$, Fk $(\square)$ or both $(\mathbf{O})$, and cells were then incubated for a further 30 minutes. Cells were harvested at the times indicated, and total RNA was extracted. IL-6 mRNAs were detected by Northern blot analysis and quantitative autoradiography. Results of the 1.2-kb IL-6 mRNA quantification were corrected for the expression of GAPDH mRNA, and the remaining mRNA is expressed as a \% of the values measured at time 0 (mean of three independent experiments). Statistical analysis: $p<0.05$ relative to unstimulated $\left({ }^{*}\right)$ or to Fk-stimulated $(\boldsymbol{\Phi})$ cells.

Fig. 5: Involvement of the cAMP/PKA signalling pathway in IL-6 promoter activity. Subconfluent (75\%) FRTL-5 cells were co-transfected with $0.8 \mu \mathrm{g}$ per well of $\mathrm{p} 1168$ luciferase reporter plasmid, and $0.2 \mu \mathrm{g}$ of pREP4- $\beta$-GAL expression vector. $24 \mathrm{~h}$ later they were incubated in deprivation medium for another 24-h period. (A) Cells were stimulated for $7 \mathrm{~h}$ with $1 \mathrm{mU} / \mathrm{ml} \mathrm{TSH}, 10 \mu \mathrm{M}$ Fk or $40 \mathrm{ng} / \mathrm{ml} \mathrm{IL}-1$ alone or in combination, as indicated. (B) Transfected cells were preincubated or not with $10 \mu \mathrm{M}$ of the PKA inhibitor $\mathrm{H} 89$, and then incubated or not with $40 \mathrm{ng} / \mathrm{ml} \mathrm{IL-1}$ alone or in combination with $10 \mu \mathrm{M} \mathrm{Fk}$, as indicated. Cell extracts were assayed for luciferase (LUC) activity, and normalized using the corresponding $\beta$-GAL activity as described in Materials and Methods. Results are expressed relative to the luciferase activities measured in unstimulated cells. The values are mean \pm SEM of triplicate culture wells and transfections. ${ }^{*} P<0.05 ;{ }^{* *} P<0.01$ versus IL-1-treated cells.

Fig. 6: Transcriptonal activation by Fk and IL-1 using luciferase reporter plasmids. FRTL-5 cells were co-transfected with $0.8 \mu \mathrm{g}$ per well of $(A)$ pGL3b, p1168, p1168$\triangle \mathrm{AP}-1, \mathrm{p} 1168-\mathrm{mCRE}, \mathrm{p} 1168-\mathrm{mNF}_{\kappa} \mathrm{B}$ or $(\mathrm{B}) \mathrm{p}(\mathrm{AP}-1)_{6}, \mathrm{p}(\mathrm{CRE})_{4}, \mathrm{p}(\mathrm{NF} \kappa \mathrm{B})_{6}$ luciferase reporter plasmids, together with $0.2 \mu \mathrm{g}$ of pREP4- $\beta$-GAL expression vector. After a $24 \mathrm{~h}$ deprivation period, transfected cells were incubated for $7 \mathrm{~h}$ with vehicle (white bars), or with $10 \mu \mathrm{M} \mathrm{Fk}$ (hatched bars in panel B), or with $40 \mathrm{ng} / \mathrm{ml} \mathrm{IL-1}$ either alone (gray bars) or in combination with $10 \mu \mathrm{M}$ Fk (black bars). Luciferase (LUC) activity was normalized using the corresponding $\beta-G A L$ activity, and results are expressed relative to the luciferase activities found for the unstimulated cells. Values are mean \pm SEM of $(A)$ four independent experiments and of $(B)$ five $\left(p(A P-1)_{6}\right)$ or two $\left(p(C R E)_{4}\right.$ and $\left.p(N F \kappa B)_{6}\right)$ independent experiments, each performed in triplicate culture wells. 
The synergy index (SI) is shown, as defined in the "Materials and Methods" section. ${ }^{*} P<0.05 ;{ }^{* *} P<0.01$ versus IL-1-treated cells.

Fig. 7: Electrophoretic mobility shift analysis (EMSA) of AP-1 and CRE binding activity. FRTL-5 cells were stimulated for $1 \mathrm{~h}$ without or with $10 \mu \mathrm{M} \mathrm{Fk}, 40 \mathrm{ng} / \mathrm{ml} \mathrm{IL}-1$, or both, as indicated. Identical amounts $(3 \mu \mathrm{g})$ of nuclear proteins were incubated with the same amounts of ${ }^{32} \mathrm{P}$-labelled oligonucleotides containing (A) AP-1 and (B) CRE sequences of the IL-6 promoter, in the presence or absence of a 200-fold excess of the unlabelled competitor. DNA-protein complexes were resolved on nondenaturing 6\%-polyacrylamide gels, and detected by quantitative autoradiography. (C) nuclear extracts were preincubated, or not, for $1 \mathrm{~h}$ with nonimmune IgG (control) or antibodies raised against the indicated AP-1 transcription factors. The specific DNA-protein complexes for AP-1, CRE or for supershifted bands are indicated by arrows. NS indicates a non-specific band present in all samples. Similar results were obtained in two other independent experiments.

Fig. 8: Expression and phosphorylation of AP-1 and CREB transcription factors in response to IL-1 and/or Fk. Confluent FRTL-5 cells were stimulated for $1 \mathrm{~h}$ without or with $10 \mu \mathrm{M} \mathrm{Fk}$, or $40 \mathrm{ng} / \mathrm{ml} \mathrm{IL-1}$, or both, as indicated. Nuclear proteins were extracted and equal amounts of protein were analyzed by Western Blot for (A) AP-1 and (B) CREB/ATF-1 expression and phosphorylation, as indicated. The membranes were stripped and reprobed with anti-HDAC1 antibody, and a representative result is shown as a loading control. Three separate experiments were performed, giving similar results. 
Figure 1

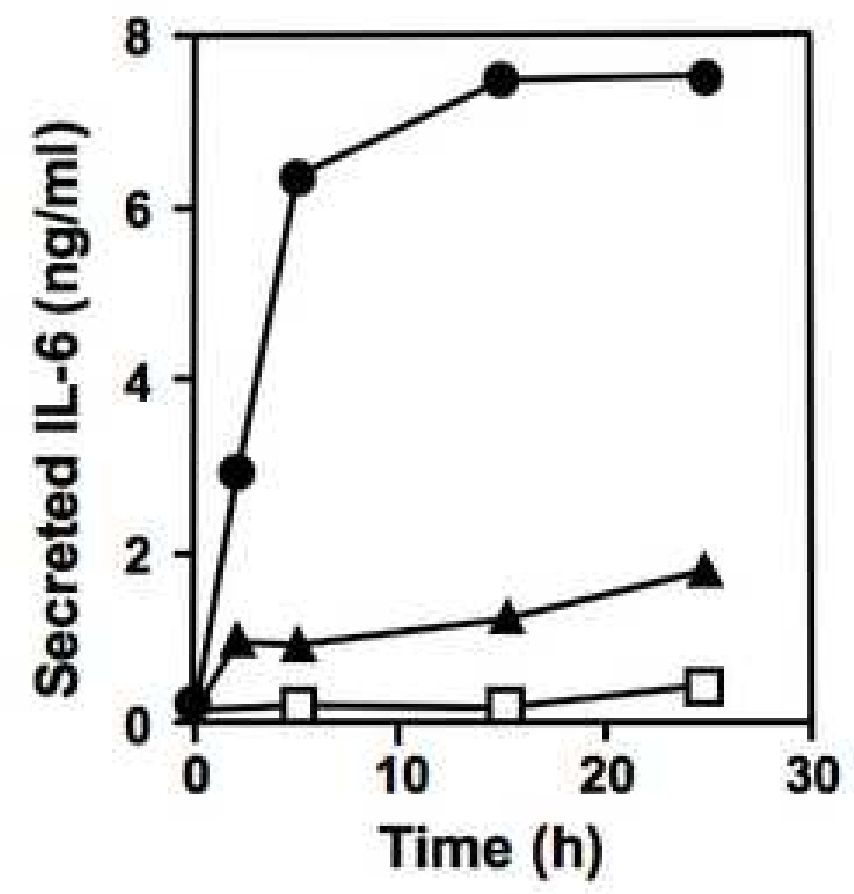


Figure 2

A

Time (h)

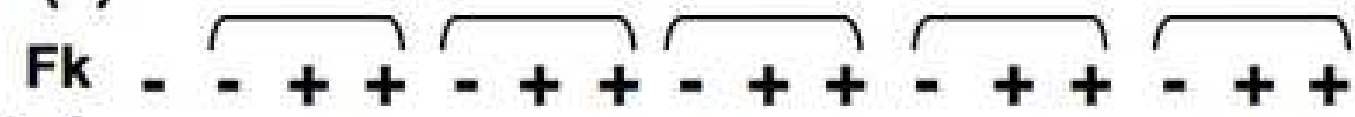

$\mathrm{IL}-1++++-++-++-++-+$

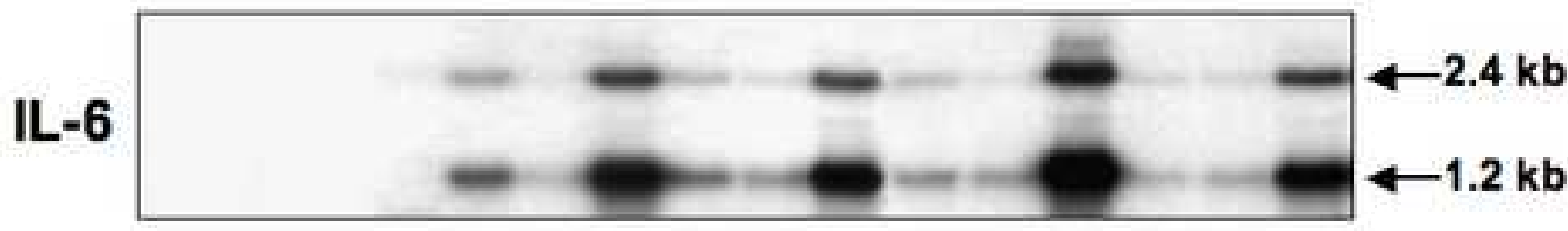

GAPDH
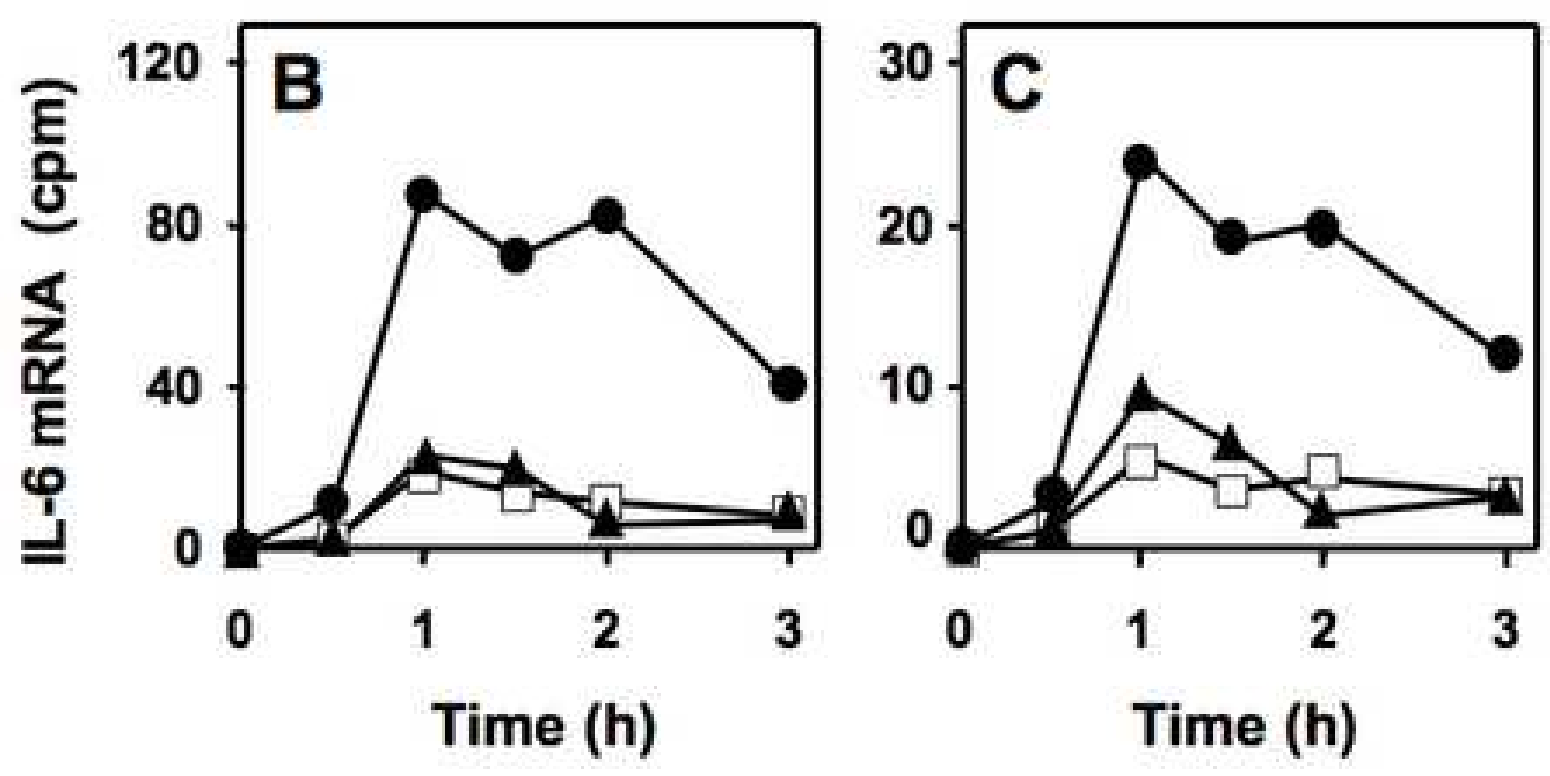
Figure 3

A
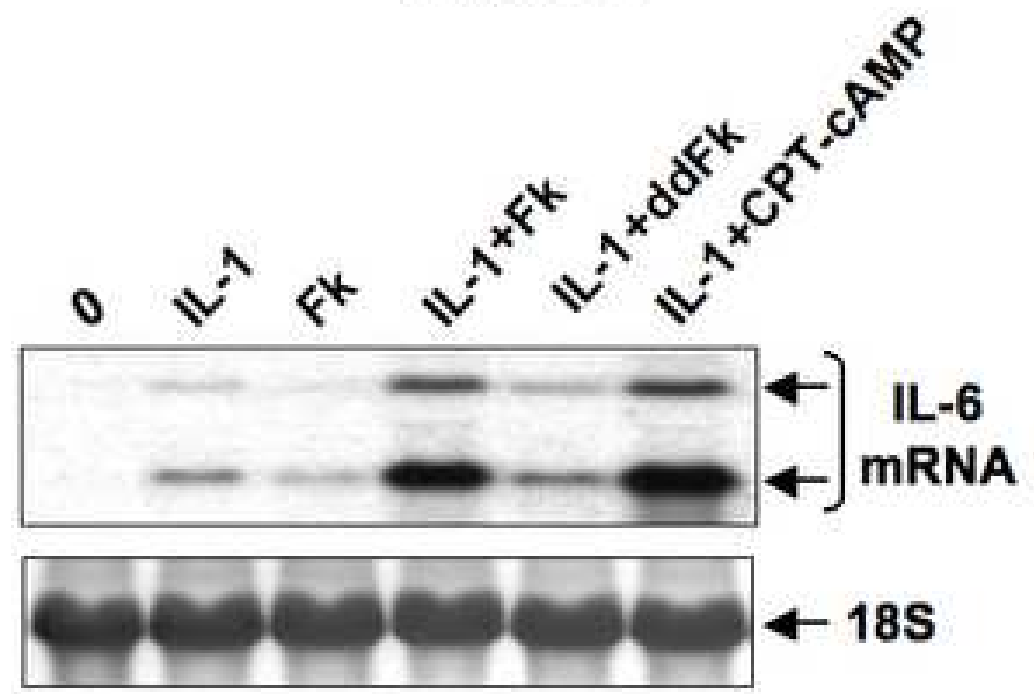

B

H89 $\frac{0}{-} \frac{\mathrm{IL}-1+\mathrm{Fk}}{-+} \quad$ H89 $\frac{0}{-} \frac{\mathrm{lL}-1+\mathrm{Fk}}{-+}$

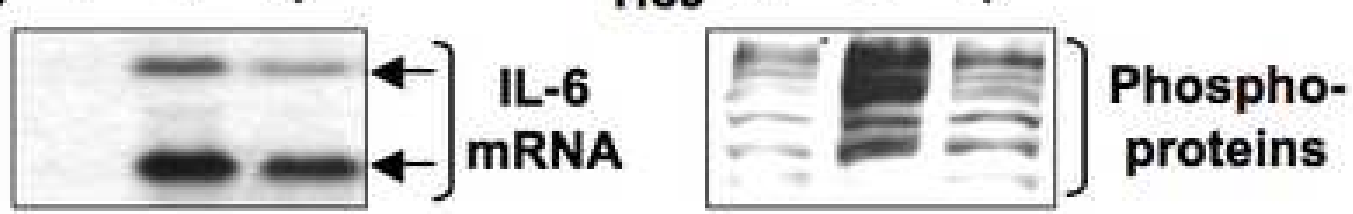

$\leftarrow$ fis $\quad \square=\alpha-$-tubulin

D

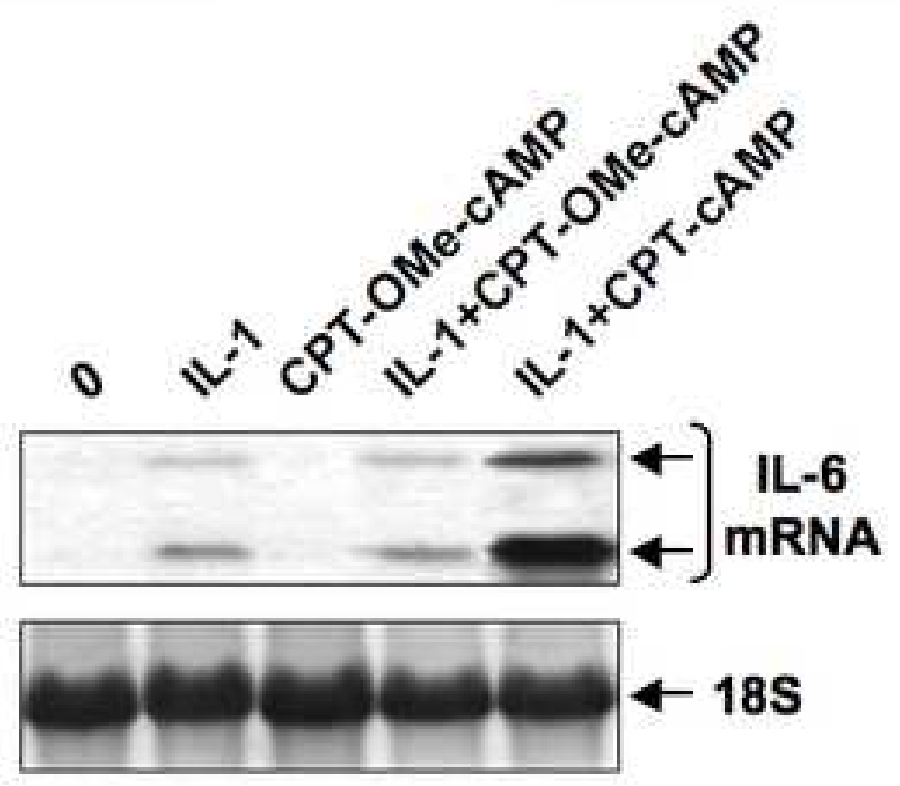




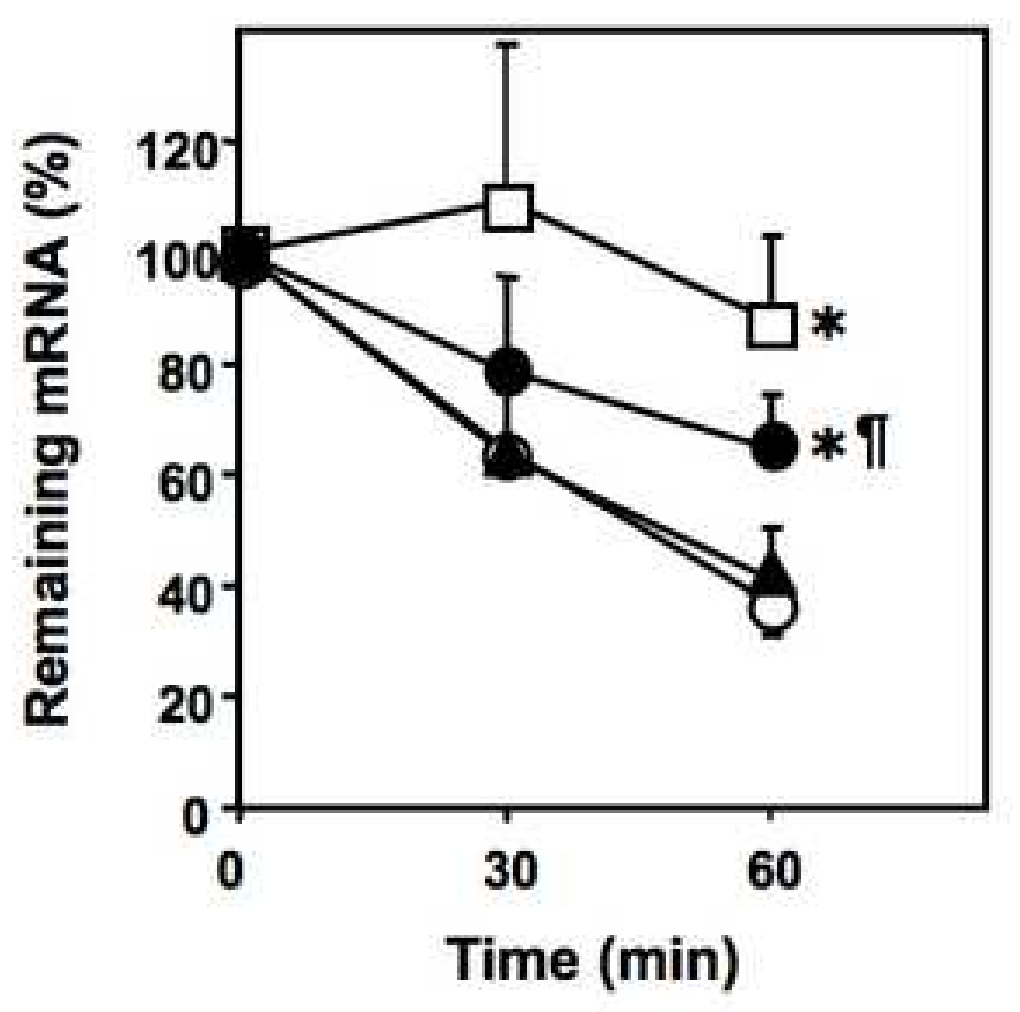

\section{Time (min)}

\section{Figure 4}

(n) 
Figure 5

A
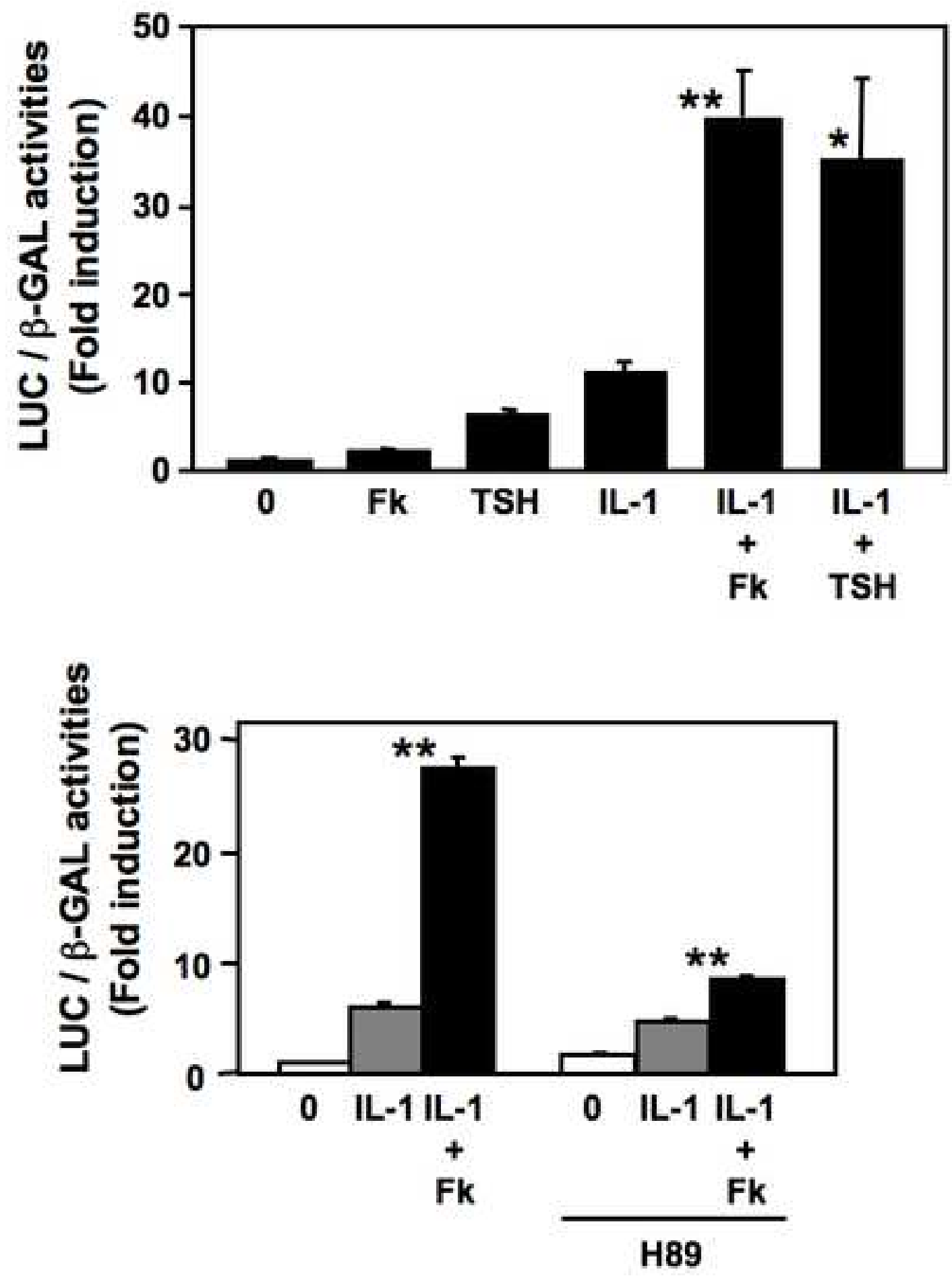
Figure 6
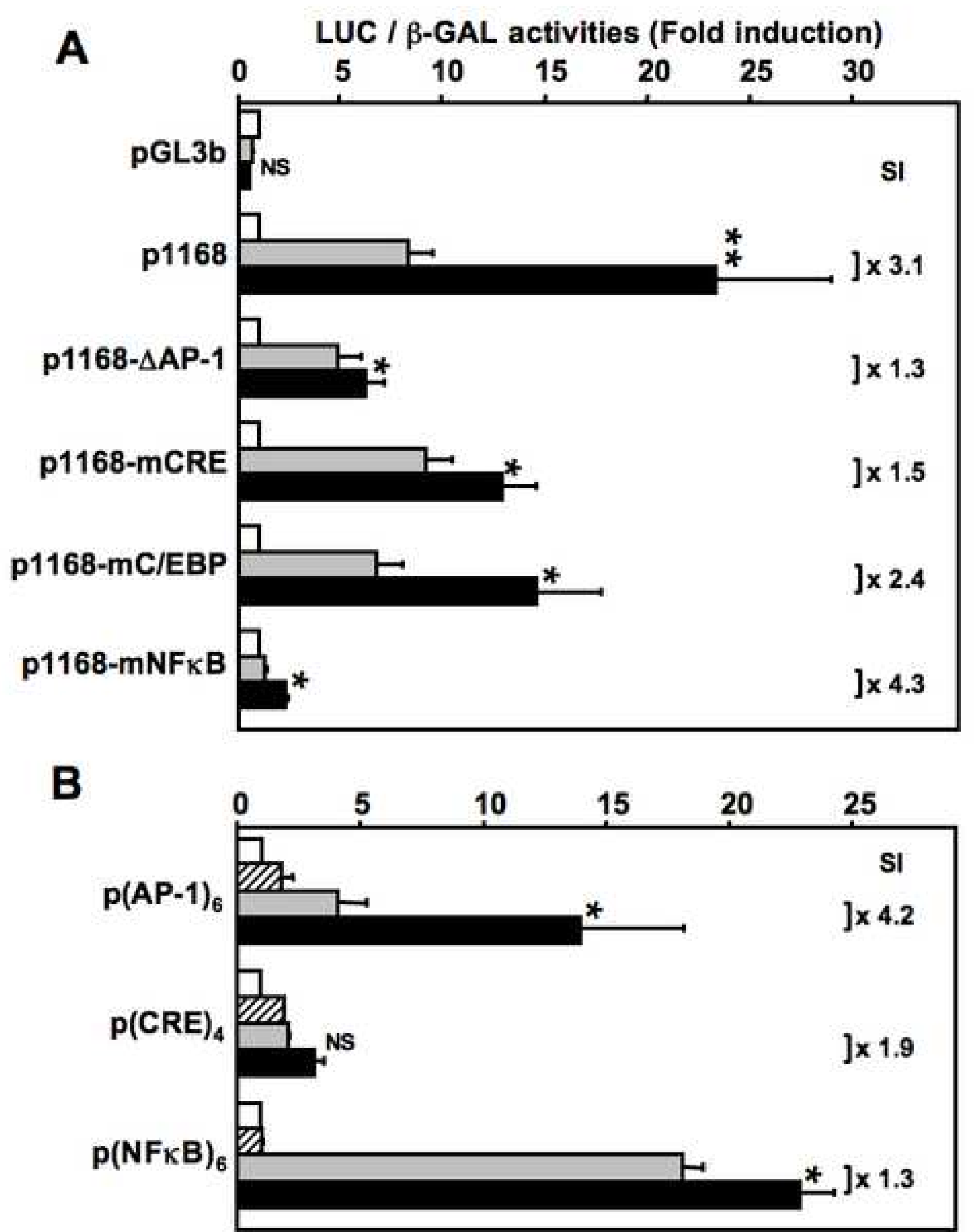
Figure 7

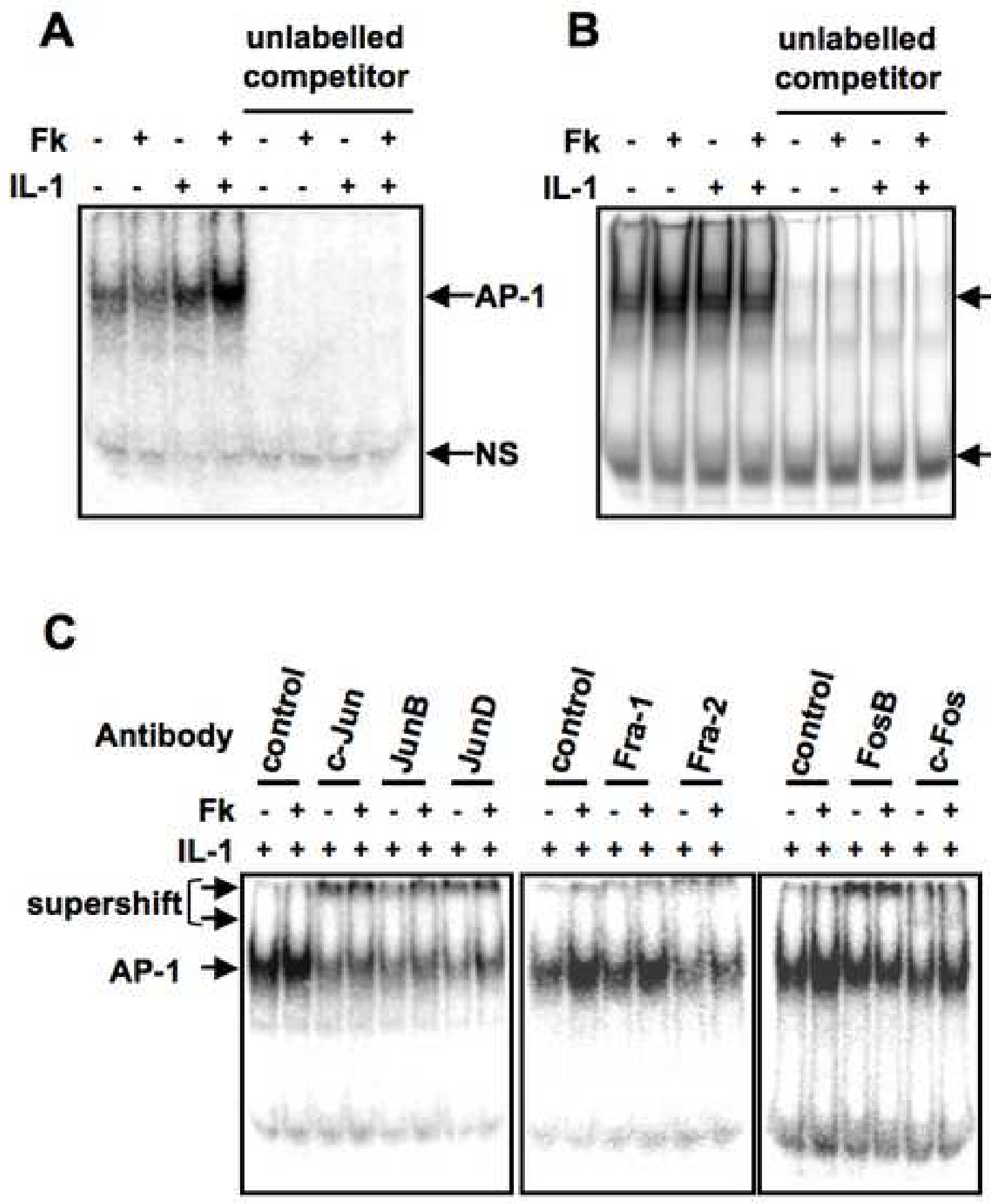


Figure 8

A Stimulation: 0 Fk IL1 IL1
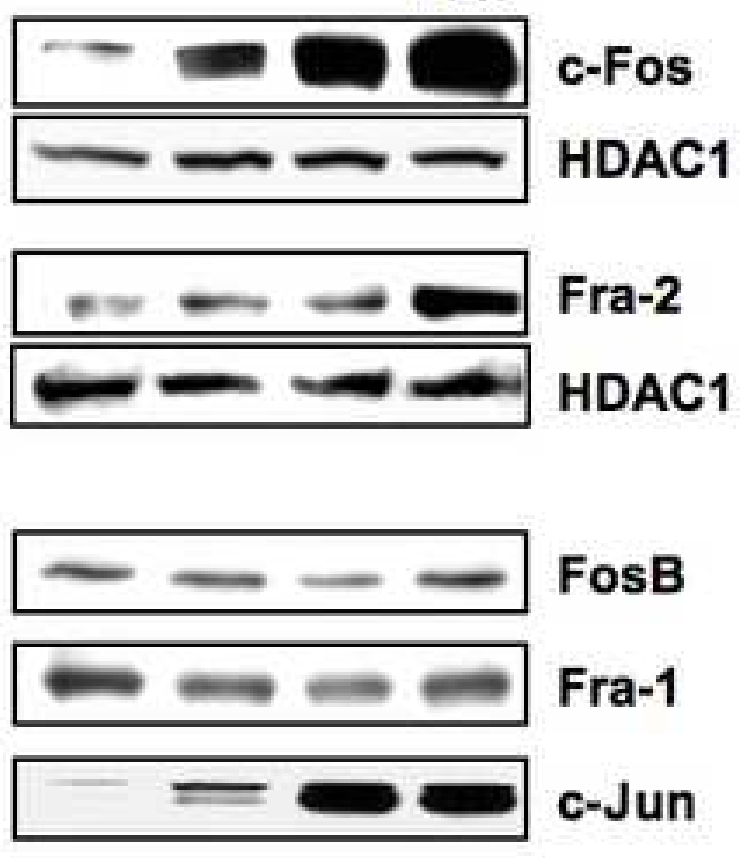

$\equiv \equiv$ JunB
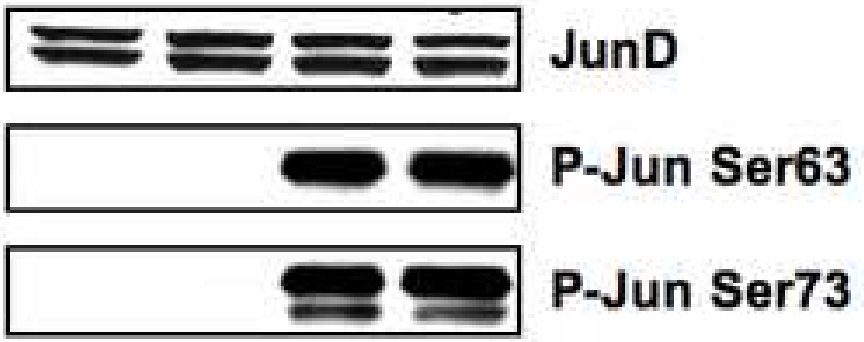

B Stimulation: 0 Fk IL1 IL1

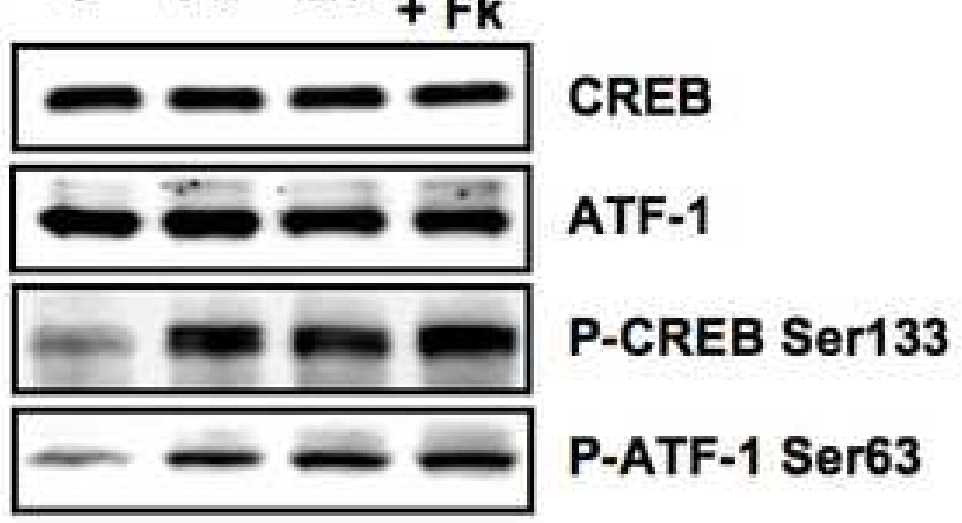

